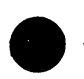

ワインに酸化防止剤としてアスコルビン酸を添加した ときの効果について教えて下さい。

(S. W. )

アスコルビン酸（ASA，ビタミンC）は，抗酸化剂と してみた場合, 還元剂 (Reducing Agent) と酸素吸収剂 (Oxygen Scavenger) としての 2 つの機能を有していま 寸。ワインに酸化防止剂として広く用いられている亚硫 酸は, これら雨者の機能に加えて, 抗菌作用, タンハク やチアミンの分解作用, ある種の酵素の阻害作用, アル デヒドとの結合作用を有していますが，ASA にはこれ らの作用は恋められません。なお, 业硫酸の還元作用は 比較的弱いものです。また，梐硫酸のワイン中での挙動 については未だ全貌が解明されていませんが，ASA の 挙動はこれにも増して複雑であり, その使用方法には充 分な注意を払ら必要があります。

なお，ASA はブドウ中にも少量存在しますが，発酵 終了時までに核消失するため, 天然の ASA による抗 酸化作用は期待できないことを果し添えておきます。

\section{ASA の抗酸化作用}

\section{(1) ASA の還元剂としての機能}

発酵前または初期のブドウ果汁の褐変の原因の 1 つに, 下に示したようなフェ：ラーゼによるオルソジフェノー ル類から黄色または褐色を呈するキノン類への变換が挙 げられます。 ASA は，フェノラーゼの作用を阻害する 機能は示さないものの, 酵素反忘生成物であるキノンを 還元して，もとのオルソジフェノールに戻すことにより， 結果として，この酵素的褐変を防止する作用を有してい ます。また，鉄含有量の多いワインは酸化還元電位が高 くなるため, 酸化傾向となって, $\mathrm{Fe}^{3+} \rightleftarrows \mathrm{Fe}^{2+}$ の平衡が 左に傾くことから，リン酸第二鉄の混濁を生ずることが あります。ASA 存在下では, ワインの酸化還元電位は 低くかつ安定に保たれ， $\mathrm{Fe}^{3+} \rightleftarrows \mathrm{Fe}^{2+}$ の平衡が右に傾き ます。このため，ASA はリン酸第二鉄の混濁の発生を 防止する作用をも有しています。な拈，ASA のこれら の還元作用は, 比較的低 $\mathrm{pH}$ で強く発現します。<smiles>[R]C1=CC(O)C(O)C=C1[Y17](=O)OCCO[PH3+]</smiles>

(2) ASA の酸素吸収剂としての機能

ASA が酸素と反応して ASA 自身が酸化されること により酸化を防止する, いわゆる酸素吸収剤として能力 は，亜硫酸のそれと比較して，(1)反応速度が大きい，(2)
1 分子当たり 2 倍の酸素を吸収する, (3)亜硫酸の場合は, 鉄または銅が存在しないと酸化されにくいのに対し， ASA は鉄, 銅が存在しなくとも反応が進行するなどの 点で，有意に優れています。しかしながら，ASA の酸 素吸収作用には，様々な波及効果が伴い，事はそう単純 には行きません。ASA は, ASA $+\mathrm{O}_{2} \rightarrow$ デヒドロアスコ ルビン酸 $(\mathrm{DHA})+\mathrm{H}_{2} \mathrm{O}_{2}$ の反応で酸素を結合し, すな わ号酸化されますが，この時副生する $\mathrm{H}_{2} \mathrm{O}_{2}$ が，酒不酸 その他のワイン中の多数の成分を酸化すると同時に, ASA 西酸化して, ASAの減少に拍車をかけてしまいま す。つまり，ASA を単独で用いると，酸化防止どころ か，むしろ酸化が促進されることになります。発生する $\mathrm{H}_{2} \mathrm{O}_{2}$ を捕足するために好適なのが喠硫酸です。亜硫酸 は, $\mathrm{H}_{2} \mathrm{O}_{2}$ と非常に素早く反応して硫酸を生成し, $\mathrm{H}_{2} \mathrm{O}_{2}$ によるワイン成分の酸化を防止してくれます。すなわち, ASA がワイン中で抗酸化作用を発揮するためには，必 ず西硫酸との併用が必要です。この場合注意しなければ ならないのは，ASA を添加することによって生ずる $\mathrm{H}_{2} \mathrm{O}_{2}$ が业硫酸と反応寸るために, 遊離业硫酸が減少す ることです。DHA も亚硫酸と反応するので，ASA と 併用する場合には, 充分量の遊離覀硫酸レベルの確保が 必須となります。このとき, 遊離严硫酸が不足すると, 前述のように, 酸化促進につながってしまいます。

なお, ASA の光学異性体であるエリソルビン酸はビ タミンCとしての活性はありませんが, アスコルビン酸 の $80 \%$ ぐらいの抗酸化力を, ASA と同一の機構で示 し, かつ比較的安価です。

\section{ASA 使用上の注意}

(1) 必要量は $25 \mathrm{mg} / l$ 以上と言われていますが, 通常, $50 \sim 100 \mathrm{mg} / l$ 存在するように, ステップ毎に補添しま す。(2) 前述のように，製成ワイン中では必ず亜硫酸と 併用し，かつ，遊離亚硫酸が充分残存するように注意し ます。(3) ASA を添加することにより，熟成の進行は 阻害されます。若いまま出荷するワイン, 熟成後のワイ ンには添加しても良いと思いますが，これから熟成しよ うとするワインには，添加しない万が良いでしょう。(4) ASA は酸化され易いので, 添加したワインが大量の酸 素と接触しないように, 注意が必要です。(5) ワインが 少量の酸素と接触する前, または輸送される前に添加す ると，かなりの効果が期待できます。(6)「酸化防止剤」 の表示が必要です。なお, 来年 7 月からは個別表示の対 象となることを付記します。 （清水健一） 